\title{
既存建物の調査結果に基づく仕上塗材の中性化抑制効果と 透気係数による中性化予測に関する研究 RESEARCH ON CARBONATION SUPPRESSIVE EFFECT OF COATING MATERIALS FOR TEXTURED FINISHES AND AIR PERMEABILITY COEFFICIENT BASED ON THE RESULT OF A SURVEY OF AN EXISTING STRUCTURE
}

\author{
唐 沢智 之*, 桝田佳寛**, 李 榮 蘭*** \\ Tomoyuki KARASAWA, Yoshihiro MASUDA and YoungRan LEE
}

\begin{abstract}
Core samples were taken from a structure several decades old, with coating materials for textured finishes, to make an accelerated carbonation test. Referring to the test result, the carbonation suppressive effect of the aged coating materials for textured finishes was evaluated on the basis of the diffusion theory. In addition, the evaluation result was compared with the prediction of carbonation progress determined from the air permeability coefficient measured at the time of the test. This comparison was intended to validate the reliability of the assessment of the carbonation suppressive effect of the coating materials for textured finishes on the aged structure, using the air permeability coefficient. This study demonstrated that the carbonation depth estimated from the air permeability coefficient, with consideration given to the aging of the coating materials for textured finishes, agreed well with the carbonation depth measured in the accelerated carbonation test.
\end{abstract}

Keywords : Coating materials for textured finishes, Carbonation suppressive effect, Carbonation depth prediction, Air permeability coefficient 仕上塗材, 中性化抑制効果, 中性化予測, 透気係数

\section{1. はじめに}

一般に、鉄筋コンクリート造建物の多くは、外壁に仕上げが施さ れており、仕上塗材は最も一般的な外装仕上材の一つである。仕上 塗材には意匠性、美観性の他、建物の耐久性の重要な評価指標であ るコンクリートの中性化を抑制することが報告 1)されている。仕上 塗材によるコンクリートの中性化抑制効果の評価方法としては、一 般的に仕上塗材を施したコンクリートと施していないコンクリート の中性化を比較することが行われているが、仕上塗材が経年変化に より劣化するために、仕上塗材による建物の耐久性を評価する場合 には、仕上塗材の劣化まで考慮した中性化抑制効果を明らかにする 必要がある。筆者らは、迅速かつ実際の建物における原位置でも中 性化を評価できる方法として、Torrent が開発したダブルチャンバ 一法 ${ }^{2)}$ (以下、トレント法)により透気係数を測定し、測定した透気係 数と中性化率の間に相関があることを明らかにした ${ }^{3)}$ 。さらに、仕 上塗材の透気係数と拡散係数との関係について理論的検討を行い、 透気係数の測定結果から求めた拡散係数、および仕上塗材の中性化 抑制効果を表す中性化抵抗より、仕上塗材を施したコンクリートの 中性化進行を予測できることを明らかにした ${ }^{4)}$ 。また、築年数が経 過した既存建物において測定した透気係数より、仕上塗材の劣化を
考慮した中性化進行を予測出来ることを明らかにした5)。

本研究では、仕上塗材が施され築年数が経過した既存建物より採 取したコア供試体を用いて促進中性化試験を行い、拡散理論に基づ き劣化した仕上塗材の中性化抵抗を確認し、同時に測定した透気係 数と中性化抵抗の関係について検討を行い、既往の研究 4、5)で明ら かにした透気係数による仕上塗材の中性化抑制効果の評価方法、お よび中性化進行予測方法の適合性の検証を行った。

\section{2. 調査概要}

\section{1 調査建物之調査箇所}

調查建物の概要は、表 1 に示寸ように、1972 年に竣工した鉄骨 鉄筋コンクリート造の共同住宅である。調查は、2009 年に実施して おり、竣工年からの築年数は 37 年である。調查対象とした部位は、 屋外に面した 2 階の大梁である。コンクリートは、設計基準強度 $225 \mathrm{~kg} / \mathrm{cm}^{2}$ の軽量コンクリートが用いられている。調查建物の仕上 塗材の種類は、建築当初が合成樹脂エマルション系複層仕上塗材(以 下、複層塗材 $\mathrm{E}$ )、改修(吹き替え)後が防水形外装合成樹脂エマルシ ヨン系薄付け仕上塗材 (以下、防水形外装薄塗材 $\mathrm{E}$ ) である。調查建 物では、築 33 年の時点で、既存の仕上塗材の上に新たに仕上塗材

\footnotetext{
* 鉄建建設(侏建設技術総合センター

** 宇都宮大学工学研究科 教授. 工博

*** 宇都宮大学工学研究科 助教 $\cdot$ 工博
}

Construction Technology Center, TEKKEN CORPORATION

Prof., Department of Design and Engineering for Global Environment, Architecture Course, Utsunomiya University, Dr. Eng.

Assistant Prof., Department of Design and Engineering for Global Environment, Architecture Course, Utsunomiya University, Dr. Eng. 
を塗り重ねる方法で改修が行われている。

\section{2 調査方法}

調査項目は、調查建物の築年数 37 年におけるコンクリートの中 性化深さ、仕上塗材の上から測定した透気係数、および調查建物か ら採取したコア供試体を用いた促進中性化試験である。

（1）ドリル法による中性化深さの測定

築年数 37 年におけるコンクリートの中性化深さの測定は、屋外 側の仕上塗材面で行い、次の(2)で透気係数を測定した個所の近傍で 行った。中性化深さの測定方法は、日本非破壊検查協会規格 NDIS 3419-1999「ドリル削孔粉を用いたコンクリート構造物の中性化深 さ試験方法(以下、ドリル法)」6)によった。なお、中性化深さは、ド リル法により測定した值から、次の(3)の採取コアを用いて実測した 平均的な仕上塗材の塗膜厚さであった $1.0 \mathrm{~mm}$ を減じた值とした。

（2）トレント法による透気係数の測定

透気係数の測定は、屋外側の仕上塗材面、および屋内側の仕上の ない打放し面において、トレント法によって行った。試験の原理は、 図 1 に示すように、内部セルと外部セルをポンプにより真空状態に した後、内部セルの圧力 $P_{s}$ と外部セルの圧力 $P_{0}$ を等しく保つため に外部セルの圧力のみをポンプにより制御することにより、周りか ら内部セルへの空気の流れが排除され、内部セルでは栓流が形成さ れ、透気係数が精度良く測定できるものである。その時の内部セル の圧力 $P_{s}$ の変化と時間 $t$ を測定することにより、ハーゲン・ポアズ イユ則における透気係数 $K$ 、および試験の影響を受けるコンクリー 卜の深さ $L$ が算出されるものである。打放しコンクリートの透気倸 数をトレント法により測定した場合、コンクリート中の圧力が定常 状態で変化すると仮定すると、試験の影響を受ける深さ $L$ 、大気圧 $P_{a}$ 、内部七ルの圧力 $P_{s}$ の関係は図 1 のように表される。一方、仕上 塗材を施したコンクリートの透気係数をトレント法により測定した 場合、測定される透気係数 $K$ は、仕上塗材のみの透気係数ではなく、 仕上塗材の下のコンクリートを含めた透気係数になる。ここで、仕 上塗材が施されたコンクリートの場合、打放しコンクリートの場合 と同様に、仕上塗材中、およびコンクリート中の圧力が定常状態で 変化すると仮定した場合、図 2 に示寸ように、仕上塗材とコンクリ 一トの界面の圧力を $P^{\prime}$ とすると、仕上塗材部分とコンクリート部 分における透気量が等しいことから関係式(1)が成り立つ。

$$
K \frac{P_{a}-P_{s}}{L_{c+f}}=K_{c} \frac{P_{a}-P^{\prime}}{l_{c}}=K_{f} \frac{P^{\prime}-P_{s}}{d_{f}}
$$

ここに、 $K:$ 仕上塗材を施した試験体の透気係数 $\left(\times 10^{-16} \mathrm{~m}^{2}\right)$

$$
P_{a}: \text { 大気圧 }\left(\mathrm{N} / \mathrm{mm}^{2}\right)
$$

$P_{s}:$ 内部セルの圧力 $\left(\mathrm{N} / \mathrm{mm}^{2}\right)$

$L_{c+f}$ : 仕上塗材を施した試験体における試験の影響を受 けるコンクリートの深さ $(\mathrm{m})$

$K_{c}$ : 仕上塗材のない試験体(打放し)の透気係数 $\left(\times 10^{-16} \mathrm{~m}^{2}\right)$

$P^{\prime}:$ 仕上塗材とコンクリートの界面の圧力 $\left(\mathrm{N} / \mathrm{mm}^{2}\right)$

$I_{c}:$ コンクリート部分の厚さ $\left(L_{c+f}-d_{f}\right)(\mathrm{m})$

$K_{f}:$ 仕上塗材のみの透気係数 $\left(\times 10^{-16} \mathrm{~m}^{2}\right)$

$d_{f}$ : 仕上塗材に含まれている樹脂質量に対する平均塗膜 厚さ(以下、樹脂塗膜厚さ $(\mathrm{m})$

式(1)より仕上塗材のみの透気係数 $K_{f}$ は式(2)により算出できる。
表 1 調査建物概要

\begin{tabular}{l||l}
\hline 所在地 & 東京都板橋区 \\
\hline 用途 & 共同住宅 \\
\hline 主体構造 & 鉄骨鉄筋コンクリート造 \\
\hline 階数 & $16 \mathrm{~F}$ \\
\hline 設計基準強度 & $225 \mathrm{~kg} / \mathrm{cm}^{2}$ \\
\hline 竣工年 & 1972 年 \\
\hline 調査年 & 2009 年 \\
\hline 築年数 & 37 年 \\
\hline 仕上塗材 & 複層塗材 $\mathrm{E}$ \\
\hline
\end{tabular}

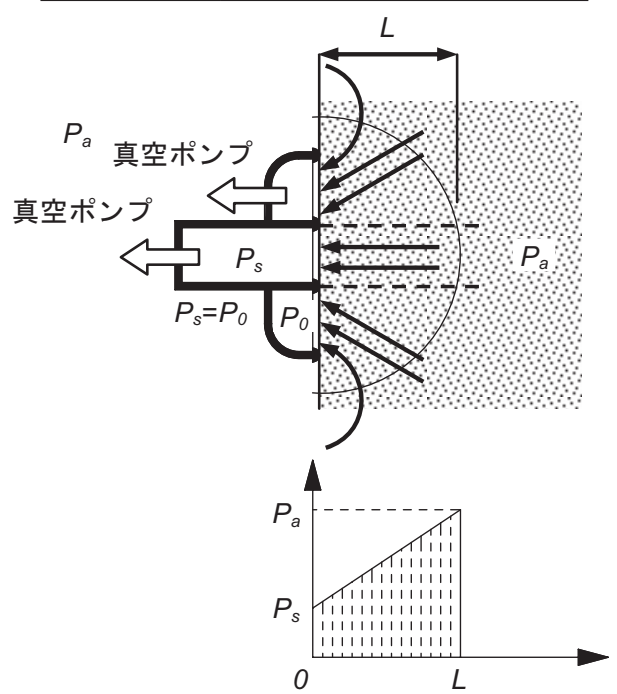

図 1 トレント法における試験の影響を受ける深さの概念図

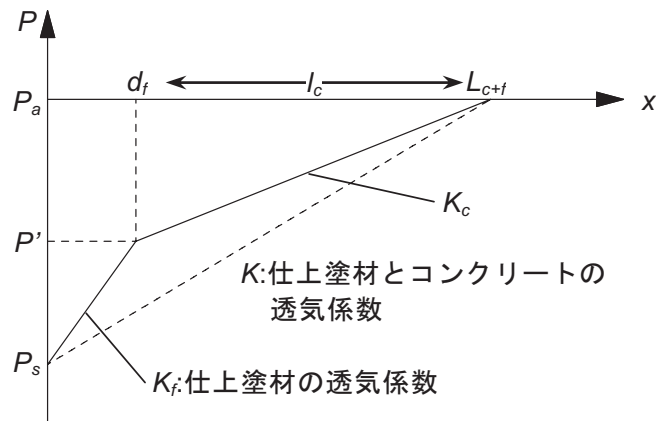

図 2 仕上塗材がある場合の圧力と透気係数の関係

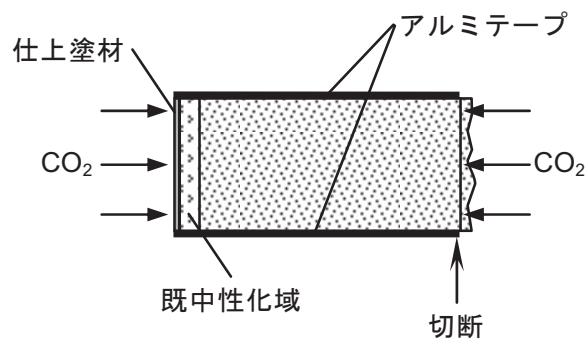

図 3 採取コアによる促進中性化試験用供試体

$$
K_{f}=\frac{K \cdot K_{c} \cdot d_{f}}{K_{c} \cdot L_{c+f}-K\left(L_{c+f}-d_{f}\right)}=\frac{K_{c} \cdot d_{f}}{\left(\frac{K_{c}}{K}-1\right) L_{c+f}+d_{f}}
$$

（3）採取コアによる促進中性化試験

前述の(1)、(2)の調查箇所の近傍から採取した $\phi 100 \mathrm{~mm}$ 、長さ $200 \mathrm{~mm}$ 程度のコア供試体を用い、促進中性化試験に供した。中性 化期間毎に 1 本、合計 4 材齢分となる 4 本を採取し、温度 $20^{\circ} \mathrm{C}$ 、 相対湿度 $60 \%$ の環境で 4 週間乾燥養生した後、促進中性化試験を開 始した。促進中性化試験にあたり、図 3 に示すように採取したコア 
供試体の側面にアルミテープを貼付け二酸化炭素を遮断し、コア供 試体の両端面を中性化試験対象面とした。コア供試体の一端面は仕 上叙材が施された面であり、もう一端面は梁の内部部分の切断面で ある。促進中性化試験の条件と測定方法を表 2 に示す。

\section{3 促進中性化試験結果の拡散理論に基づく検討}

二酸化炭素が仕上塗材および中性化したコンクリート中をフィッ クの第一法則に従って拡散していくと仮定し、調查建物から採取し たコア供試体を用いた促進中性化試験において、仕上塗材が施され たコンクリートの中性化進行について理論的に検討を行った。促進 中性化試験のモデルを図 4 に示す。

（1）仕上塗材がない切断面

仕上塗材がない場合、深さ方向に直角な面の面積 $S$ あたりを $\Delta t$ 時間に中性化したコンクリート中を拡散して深さ $x$ に達する二酸化 炭素の量 $\triangle \mathrm{CO}_{2}$ は式(3)で表される。また、中性化領域を拡散してき た二酸化炭素が、厚さ $\Delta x$ の境界領域に存在する $\mathrm{Ca}(\mathrm{OH})_{2}$ と瞬時に 反応して $\mathrm{CaCO}_{3}$ になる時に消費される二酸化炭素の量 $\triangle \mathrm{CO}_{2}$ は式 (4)で表される。

$$
\begin{aligned}
\Delta C O_{2}= & D_{c} \cdot \frac{C_{0}}{x} \cdot S \cdot \Delta t \\
\Delta C O_{2}= & \Delta x \cdot S \cdot H \\
\text { ここに、} & C_{0}: \text { コンクリート表面の } \mathrm{CO}_{2} \text { 濃度 } \\
& D_{c}: \text { コンクリートの } \mathrm{CO}_{2} \text { 拡散係数 } \\
& x: \text { 中性化深さ } \\
& t: \text { 時間 } \\
& S: \text { 面積 } \\
& H: \text { コンクリートの単位体積あたりの } \mathrm{Ca}(\mathrm{OH})_{2} \text { 量 } \\
& \Delta x \text { : 境界領域の厚さ } \\
& \Delta t \text { : 微小時間 } \\
\Delta t \rightarrow 0 \text { とすれば次の微分方程式が得られる。 } & \frac{d x}{d t}=\frac{D_{c} \cdot C_{0}}{H}
\end{aligned}
$$

切断面側は、中性化していないため $t=0$ のとき $x=0$ として、両辺 を積分する。

$$
\begin{aligned}
& \int_{0}^{x} x d x=\frac{D_{c} \cdot C_{0}}{H} \int_{0}^{t} d t \\
& \frac{x^{2}}{2}=\frac{D_{c} \cdot C_{0}}{H} \cdot t \\
& x=\sqrt{\frac{2 \cdot D_{c} \cdot C_{0}}{H}} \cdot \sqrt{t} \\
& \sqrt{\frac{2 \cdot D_{c} \cdot C_{0}}{H}}=A_{5} \text { とおくと、A } A_{5} \text { は } \mathrm{CO}_{2} \text { 濃度が } 5 \% \text { の場合の中性化 }
\end{aligned}
$$
速度係数となる。

$$
x=A_{5} \sqrt{t}
$$

\section{（2）仕上塗材がある面}

仕上塗材がある場合、材齢 $t$ にコンクリートの表面から深さ $x$ の 位置まで中性化が進行した定常状態において、深さ方向に直角な面 の面積 $S$ あたりを $\Delta t$ 時間に仕上塗材を拡散してコンクリート表面 に達する二酸化炭素の量 $\triangle \mathrm{CO}_{2}$ は式(6)で表される。また、中性化し たコンクリート中を拡散する二酸化炭素の量、さらに、未中性化域 で反応する二酸化炭素の量 $\Delta \mathrm{CO}_{2}$ は式(7)、式(8)で表される。

$$
\Delta C O_{2}=D_{f} \cdot \frac{C_{0}-C^{\prime}}{d_{f}} \cdot S \cdot \Delta t
$$

表 2 促進中性化試験条件と測定方法

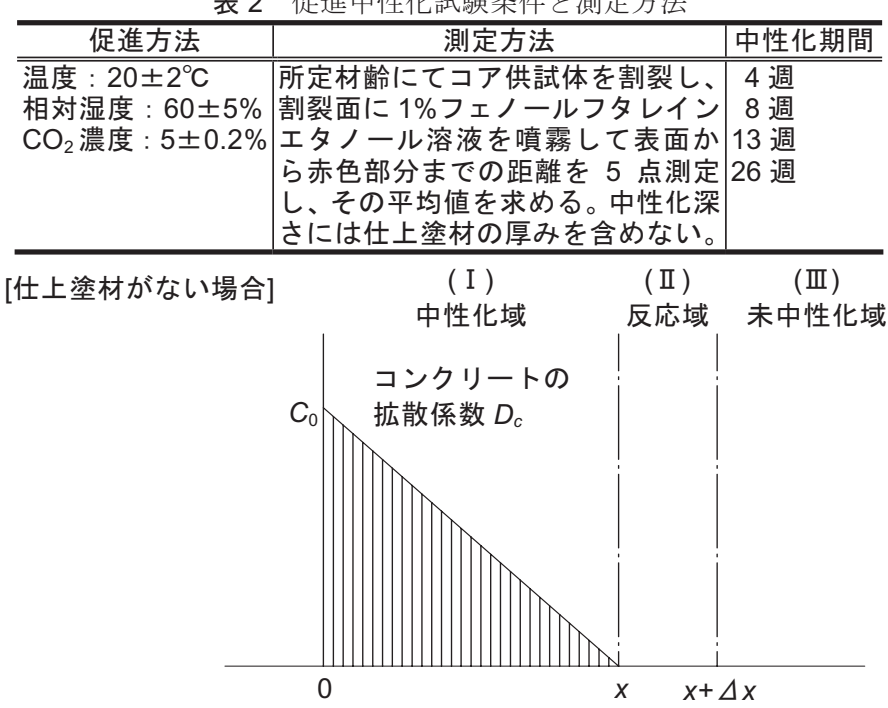

[仕上塗材がある場合]
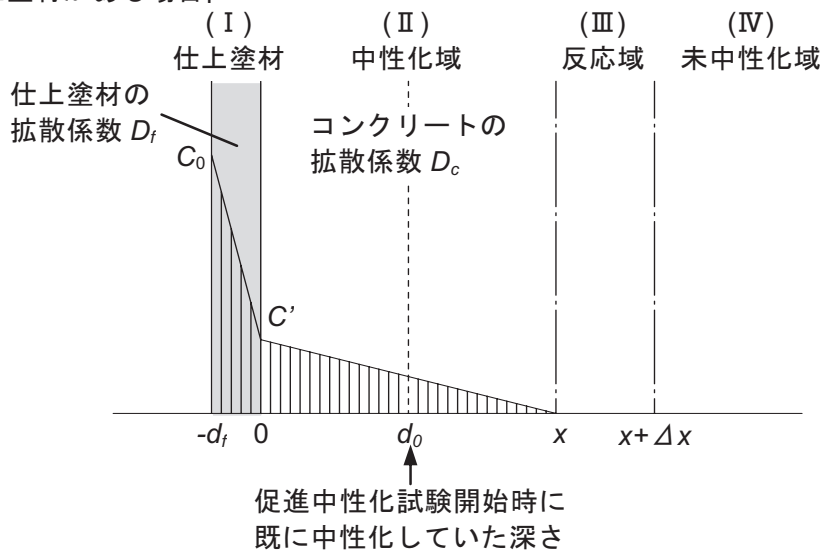

図 4 促進中性化試験のモデル

$$
\begin{aligned}
\Delta C O_{2} & =D_{c} \cdot \frac{C^{\prime}}{x} \cdot S \cdot \Delta t \\
\Delta C O_{2} & =\Delta x \cdot S \cdot H
\end{aligned}
$$

ここに、 $C_{0}$ : 仕上塗材表面の $\mathrm{CO}_{2}$ 濃度(式(3)におけるコンクリー 卜表面の $\mathrm{CO}_{2}$ 濃度と同じ)

$C^{\prime}$ : 仕上塗材とコンクリートとの界面の $\mathrm{CO}_{2}$ 濃度

$D_{f}$ : 仕上塗材の $\mathrm{CO}_{2}$ 拡散係数

$d_{f}:$ 仕上塗材の樹脂塗膜厚さ

式(6)、(7)、(8)の二酸化炭素の量が等しいことより

$$
\frac{\Delta x}{\Delta t}=\frac{D_{c}}{H} \cdot \frac{C^{\prime}}{x}=\frac{D_{c}}{H} \cdot \frac{D_{f}}{D_{f} \cdot x+D_{c} \cdot d_{f}} \cdot C_{0}
$$

$\Delta t \rightarrow 0$ とすれば次の微分方程式が得られる。

$$
\left(D_{f} \cdot x+D_{c} \cdot d_{f}\right) \frac{d x}{d t}=\frac{D_{c} \cdot D_{f} \cdot C_{0}}{H}
$$

仕上塗材側は、促進中性化試験開始時に深さ $d_{0}$ まで中性化が進行 しているから $t=0$ のとき $x=d_{0}$ として、両辺を積分する。

$$
\begin{aligned}
& \int_{d_{0}}^{x}\left(D_{f} \cdot x+D_{c} \cdot d_{f}\right) d x=\int_{0}^{t} \frac{D_{c} \cdot D_{f} \cdot C_{0}}{H} d t \\
& \frac{1}{2} D_{f} \cdot x^{2}+D_{c} \cdot d_{f} \cdot x=\frac{D_{c} \cdot D_{f} \cdot C_{0}}{H} \cdot t+\frac{1}{2} D_{f} \cdot d_{0}{ }^{2}+D_{c} \cdot d_{f} \cdot d_{0} \\
& \left(x+\frac{D_{c} \cdot d_{f}}{D_{f}}\right)^{2}=\frac{2 \cdot D_{c} \cdot C_{0}}{H} \cdot t+\left(d_{0}+\frac{D_{c} \cdot d_{f}}{D_{f}}\right)^{2}
\end{aligned}
$$




$$
\begin{aligned}
& x=\sqrt{\frac{2 \cdot D_{c} \cdot C_{0}}{H} \cdot t+\left(d_{0}+\frac{D_{c} \cdot d_{f}}{D_{f}}\right)^{2}}-\frac{D_{c} \cdot d_{f}}{D_{f}} \\
& x=\sqrt{\frac{2 \cdot D_{c} \cdot C_{0}}{H}}\left\{\sqrt{t+\frac{H}{2 \cdot D_{c} \cdot C_{0}}\left(d_{0}+\frac{D_{c} \cdot d_{f}}{D_{f}}\right)^{2}}-\sqrt{\frac{H}{2 \cdot D_{c} \cdot C_{0}}}\left(\frac{D_{c} \cdot d_{f}}{D_{f}}\right)\right\}(9)
\end{aligned}
$$$$
\sqrt{\frac{2 \cdot D_{c} \cdot C_{0}}{H}}=A_{5}, \sqrt{\frac{H}{2 \cdot D_{c} \cdot C_{0}}}\left(\frac{D_{c} \cdot d_{f}}{D_{f}}\right)=R_{5}, \frac{D_{c} \cdot d_{f}}{D_{f}}=B
$$

とおくと、式(9)は式(10)のように表される。

$$
x=A_{5}\left\{\sqrt{t+\frac{1}{A_{5}^{2}}\left(d_{0}+B\right)^{2}}-\frac{B}{A_{5}}\right\}
$$

切断面側の促進中性化試験の結果より、式(5)の $A_{5}$ が求まり、こ の $A_{5}$ の值を式(10)に代入して、式(10)の $B$ および $d_{0}$ を最小二乗法 により求める。また、 $A_{5}$ と $B$ から $R_{5}$ が求まる。

なお、仕上塗材が施されたコンクリートの中性化進行については、 $t=0$ のとき $x=0$ で仕上塗材が中性化期間中に劣化しないものとした 場合、中性化深さは式(11)で表せ 7)、式(11)の中性化抵抗 $R$ は、式(12) で表せる7。

$$
\begin{aligned}
& x=A\left(\sqrt{t+R^{2}}-R\right) \\
& R=\frac{D_{c}}{\left(\frac{D_{f}}{d_{f}}\right)} \cdot \frac{1}{A}
\end{aligned}
$$

従って、促進中性化試験で求めた $R_{5}$ は、築年数 37 年時点での促 進中性化試験条件における中性化抵抗 $(\sqrt{ }$ 週 $)$ と言える。

\section{3. 調査結果}

\section{1 促進中性化試験結果}

促進中性化試験の結果を表 3 、図 5 に示す。なお、試験開始時の 中性化深さの測定值は、仕上塗材面についてはドリル法による中性 化深さの測定值、切断面については試験対象面が梁の内部であり中 性化していないため $0 \mathrm{~mm}$ とした。各材齢毎、異なるコア供試体に より中性化深さを測定しているため、ばらつきが大きいものの、材 齢が進むにつれて中性化深さが大きくなる傾向を示した。切断面お よび仕上塗材面の各材齢の中性化深さの測定結果より、 $A_{5} 、 B 、 d_{0}$ 、 および $R_{5}$ を最小二乗法により求めた結果、 $A_{5}=8.92 \mathrm{~mm} / \sqrt{ }$ 週、 $B=22.16 \mathrm{~mm} 、 d_{0}=16.04 \mathrm{~mm} 、 R_{5}=2.48 \sqrt{ }$ 週となった。

\section{2 仕上塗材の透気係数測定結果}

透気係数 $K$ の調查結果を表 4 に示す。

仕上塗材の拡散係数 $D_{f}$ は、式(12)より式(13)で表せる。

$$
D_{f}=\frac{D_{c}}{A_{5} \cdot R_{5}} \cdot d_{f}
$$

仕上塗材の拡散係数については、既報 ${ }^{4}$ において、仕上塗材の透 気係数と相関が認められることを報告した。既報 3、4)では、劣化し ていない仕上塗材を施した試験体を用い、促進中性化試験結果より 求めた中性化抵抗を式(12)に代入して求めた仕上塗材の拡散係数と、 透気係数の測定結果を式(2)に代入して求めた仕上叙材の透気係数 の関係について考察を行った。既報 3.4)における透気係数の測定結 果より算出した仕上塗材の拡散係数と透気係数の関係を図 6 に示す。 図 6 の結果は、劣化していない仕上塗材を施した試験体によるもの

\begin{tabular}{|c|c|c|c|c|}
\hline & $\begin{array}{l}\text { 調査 } \\
\text { 部位 }\end{array}$ & $\begin{array}{c}\text { 透気係数 } \\
\left(\mathrm{m}^{2}\right)^{-}\end{array}$ & 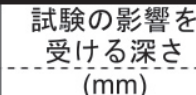 & $\begin{array}{c}\text { 仕上塗材の } \\
\text { 透気係数※1 } \\
\left(\mathrm{m}^{2}\right)\end{array}$ \\
\hline \multirow[t]{6}{*}{$2 \mathrm{~F}$ 梁 } & \multirow[t]{4}{*}{ 屋外 } & $1.21 \times 10^{-}$ & 45.8 & $1.35 \times 10^{-19}$ \\
\hline & & $7.48 \times 10^{-}$ & 40.9 & $9.29 \times 10^{-20}$ \\
\hline & & $K \quad 3.86 \times 1$ & 62.7 & $K_{f}: 3.21 \times 10^{-19}$ \\
\hline & & $8.84 \times 11$ & 41.3 & $1.09 \times 10^{-19}$ \\
\hline & 平均 & $1.68 \times 10^{-}$ & 47.7 & $1.64 \times 10^{-19}$ \\
\hline & 屋内 & $\begin{array}{c:c}K_{c} & 1.26 \times 10^{-}\end{array}$ & 251.1 & \\
\hline
\end{tabular}
であるが、劣化した仕上塗材についても、仕上塗材の拡散係数と透
表 3 促進中性化試験結果

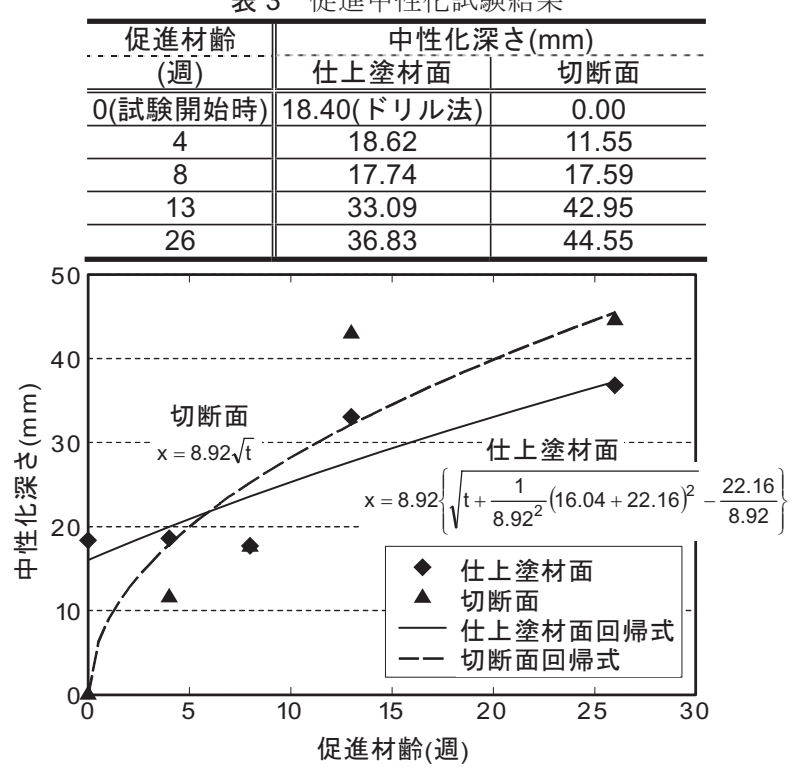

図 5 拡散理論に基づいた中性化進行 表 4 透気係数調查結果

※1: 仕上塗材の透気係数は後述の $d_{f}$ の值を用いて算出した。

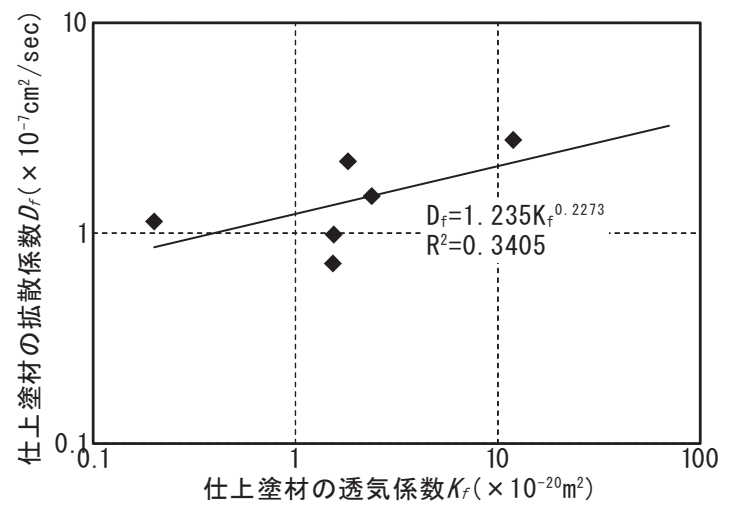

図 6 仕上塗材の拡散係数と透気係数の関係

気係数の関係は、同様であると仮定すると、仕上塗材の拡散係数 $D_{f}$ は、式(14)により算出できる。

$$
D_{f}=1.235 \cdot K_{f}^{0.2273}
$$

ここに、 $D_{f}$ : 仕上塗材の拡散係数 $\left(\times 10^{-7} \mathrm{~cm}^{2} / \mathrm{s}\right)$

$K_{f}:$ 仕上塗材の透気係数 $\left(\times 10^{-20} \mathrm{~m}^{2}\right)$

式(2)、式(13)、式(14)より、式(15)が成り立つ。

$$
1.235 \cdot\left[\frac{K_{c} \cdot d_{f}}{\left(K_{c} / K-1\right) L_{c+f}+d_{f}}\right]^{0.2273}=\frac{D_{c}}{A_{5} \cdot R_{5}} \cdot d_{f}
$$

$K_{c} 、 K 、 L_{c+f}$ は透気係数の測定結果より、 $A_{5} 、 R_{5}$ は促進中性化試 験結果より求まる。 $d_{f}$ にいては、筆者らが行った既往の実験式 8$)$ より求めた。筆者らは、カーボンアークランプ式の耐候性促進試験 機により劣化させた仕上塗材を施したコンクリートの促進中性化試 験を行い、仕上塗材の劣化により中性化抑制効果が低下寸ることを 
明らかにし、中性化抵抗を樹脂塗膜厚さで除した樹脂塗膜厚さに対 する中性化抵抗と劣化年数との関係は、式(16)、式(17)で表される ことを報告した ${ }^{8)}$ 。

$$
\begin{aligned}
& \frac{R_{5}}{d_{f}}=-0.0098 t+0.088 \quad[t \leqq 6] \\
& \frac{R_{5}}{d_{f}}=-0.0018 t+0.041 \quad[6<t \leqq 12] \\
& \text { ここに、 } R_{5} \text { : 中性化抵抗 }(\sqrt{ } \text { 週 }) \\
& d_{f} \text { : 樹脂塗膜厚さ }(\mu \mathrm{m}) \\
& t \text { : 劣化年数(年) }
\end{aligned}
$$

劣化年数 12 年以降も劣化年数 6 年から 12 年と同じ割合で樹脂塗 膜厚さに対する中性化抵抗が低下していくと仮定すると、劣化年数 23 年で樹脂塗膜厚さに対する中性化抵抗は 0 となる。従って、改修 を行った 33 年時点での改修前の仕上塗材については、経年劣化が 生じ、中性化抑制効果が期待できないと考えられるので、改修前の 仕上塗材の樹脂塗膜厚さは 0 と仮定した。すると、37 年時点の中性 化抵抗は、改修後の仕上塗材の中性化抵抗と見なせ、改修後 4 年目 の中性化抵抗となる。促進中性化試験結果より求めた中性化抵抗と 改修からの年数を式(16)に代入し、改修後の仕上塗材の樹脂塗膜厚 さ $d_{f}$ を算出すると $50.5 \mu \mathrm{m}$ であった。改修後の仕上塗材(防水形外 装薄塗材 $\mathrm{E}$ )の樹脂塗膜厚さは、後述する複層塗材 $\mathrm{E}$ の樹脂塗膜厚 さよりも薄くなっており、仕上塗材の塗布量が標準塗布量よりも少 なかったと推察される。

以上より式(15)における未知数は、コンクリートの拡散係数 $D_{c}$ のみとなり、算出すると $10.5 \times 10^{-5} \mathrm{~cm}^{2} / \mathrm{s}$ となった。ここで、コン クリートの拡散係数 $D_{c}$ は、中性化速度係数 $A$ の 2 乗に比例し、ま た同水セメント比の軽量コンクリートの中性化速度係数は、普通コ ンクリートの 1.2 倍 ${ }^{9)}$ とれているので、軽量コンクリートの拡散 係数は、普通コンクリートの 1.44 倍となる。設計基準強度 225 $\mathrm{kg} / \mathrm{cm}^{2}$ に対応する水セメント比は、建築時の JASS 5(1969)10)に従 って算出すると $64.2 \%$ となり、既往の研究 7において同程度の水セ メント比のモルタル板を用いて測定した拡散係数が $9.84 \times$ $10^{-5} \mathrm{~cm}^{2} / \mathrm{s}$ であるので、軽量コンクリートの拡散係数は、その 1.44 倍である $14.2 \times 10^{-5} \mathrm{~cm}^{2} / \mathrm{s}$ であり、促進中性化試験、および透気係 数の測定結果から求めた拡散係数とほぼ一致した。従って、透気係 数による仕上塗材の中性化抑制効果の評価方法、および既往の実験 式による中性化抵抗の経年変化の予測は、妥当であったと考えられ る。

\section{4. 仕上塗材の経年劣化を考慮した中性化進行予測}

\section{1 中性化抵抗の経年変化}

中性化抵抗の経年変化は、式(16)、式(17)で表される。ただし、 式(16)、式(17)による中性化抵抗は、炭酸ガス濃度 $5 \%$ の促進中性化 試験の結果から導かれたものなので、実構造物の劣化年数に合わせ

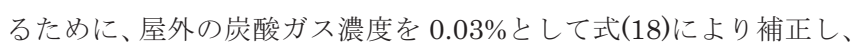
屋外暴露条件での中性化抵抗の経年変化とした。

$$
\begin{aligned}
& R=\frac{R_{5}}{\sqrt{52 \times C O_{2} / 5}} \\
& \text { ここに、R: 屋外暴露における中性化抵抗 }(\sqrt{ } \text { 年 }) \\
& R_{5}: \text { 促進中性化試験における中性化抵抗 }(\sqrt{ } \text { 週 }) \\
& C O_{2}: \text { 屋外の炭酸ガス濃度 }(0.03 \%)
\end{aligned}
$$

建築時の仕上塗材(複層塗材 $\mathrm{E}$ )の樹脂塗膜厚さは、今回調查した 建物では明らかではなかった。そこで、仕上塗材の樹脂塗膜厚さは、 国土交通省の公共建築工事標準仕様書 11)(以下、標準仕様書)の所要 量と建設省の建築工事共通仕様書 12)(以下、共通仕様書)の塗布量、 および国内の主要メーカー4 社のカタログの標準塗布量を参考に算 出した。仕上塗材の塗布量の標準值を表 5 に示寸。調查建物の建築 時の共通仕様書には塗布量の記述がなかった。一方、共通仕様書に 塗布量が記述された昭和 60 年版、および現在の標準仕様書平成 17 年版の所要量を比較して見ると、塗布量に大きな差は見られなかっ た。従って、調査建物の建築時から、共通仕様書、標準仕様書にお ける塗布量は大きく変化していないと仮定した。また、主要メーカ 一の標準塗布量は、標準仕様書平成 17 年版の所要量を挟んで、メ 一カー間で若干の差異が見られる。以上より、塗布量の標準値は、 標準仕様書平成 17 年版の所要量程度と考えられるが、実施工時の 施工環境等により生じる塗厚さのばらつきを考慮し、主要メーカー

\begin{tabular}{|c|c|c|c|c|c|}
\hline & \multicolumn{4}{|c|}{ 複層塗材 $\mathrm{E}\left(\mathrm{kg} / \mathrm{m}^{2}\right)$} \\
\hline & & 下塗材 & 主材基層 & \begin{tabular}{|l} 
主材模様 \\
\end{tabular} & 上塗材 \\
\hline $\begin{array}{l}\text { 公共建築工事 } \\
\text { 標準仕様書 }\end{array}$ & $\begin{array}{l}\text { 平成 } \\
17 \text { 年版 }\end{array}$ & 0.10 以上 & 0.70 以上 & 0.80 以上 & 0.25 以上 \\
\hline $\begin{array}{l}\text { 建築工事 } \\
\text { 共通仕様書 }\end{array}$ & $\begin{array}{l}\text { 昭和 } \\
60 \text { 年版 }\end{array}$ & 0.10 以上 & 1.50 & 以上 & 0.30 以上 \\
\hline メーカー & 最小 & 0.07 & 0.40 & 0.40 & 0.18 \\
\hline 標準塗布量 & 最大 & 0.17 & 0.85 & 0.85 & 0.40 \\
\hline
\end{tabular}
の標準塗布量の最小值とした。一方、主材模様については、凹凸が 生じるため塗膜厚さが不均一となり、透気係数は塗膜厚さが薄い凹 部分における数值として測定されると考えられるため、凹部分を評 価対象とすることとした。テクスチャーの凹部分の塗膜厚さは、平 均塗膜厚さの 0 ～60\%と報告されているので 13$)$ 、その中央值の $30 \%$ を主材模様の塗膜厚さとした。以上の塗布量を基に算出した仕上塗 材の樹脂塗膜厚さを表 6 に示す。

表 5 仕上塗材の塗布量の標準值

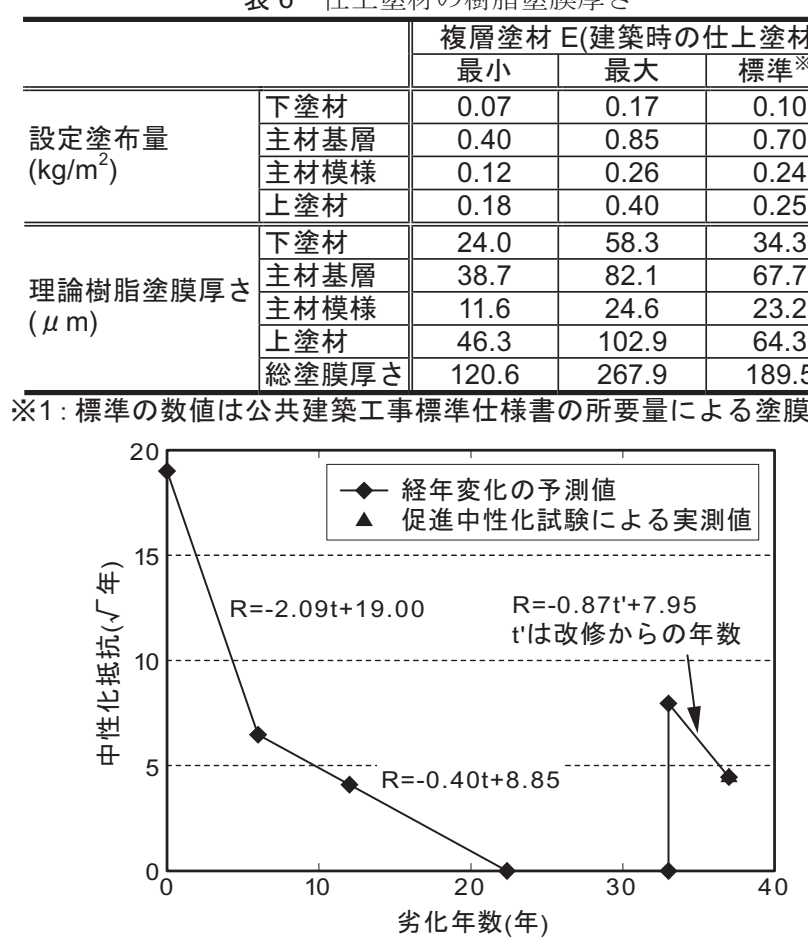

図 7 中性化抵抗の経年変化 
表 6 の建築時の仕上塗材の樹脂塗膜厚さ、および前述の改修後の 仕上塗材の樹脂塗膜厚さを式(16)、式(17)に代入して算出した仕上 塗材の中性化抵抗の経年変化を図 7 に示寸。

\section{2 透気係数による中性化予測}

筆者らが提案した仕上塗材の経年劣化を考慮した中性化進行モデ ル 14) と、中性化深さの実測值の比較を行い、仕上塗材の経年劣化を 考慮した透気係数による中性化深さの推定方法の検証を行った。式 （19）による仕上塗材の経年劣化を考慮した中性化進行予測を図 8 に 示寸。なお、中性化速度係数 $A$ は、促進中性化試験より得られた值 を式(20)により補正して用いた。

$$
\begin{aligned}
& X=A\left(\sqrt{t+R_{i}^{2}+\frac{2}{A}\left\{\left(R_{i}-R_{i-1}\right) x_{i}+\left(R_{i-1}-R_{i-2}\right) x_{i-1}+\cdots+\left(R_{1}-R_{0}\right) x_{1}\right\}}-R_{i}\right) \text { (19) } \\
& \text { ただし、 } \dot{I}=0 \text { の時 } \\
& X=A\left(\sqrt{t+R_{0}^{2}}-R_{0}\right) \\
& \text { ここに、 } X \text { : 時間 } t\left(t \geqq T_{i} 、 \dot{I}=0,1,2, \cdots\right) \text { におけるコンクリートの中 } \\
& \text { 性化深さ }(\mathrm{mm})
\end{aligned}
$$

年)

$$
\text { ただし、 } R_{i}=\frac{D_{c}}{\left(\frac{D_{f i}}{d_{f}}\right)} \cdot \frac{1}{A}
$$

$D_{f i}$ : 時間 $t\left(T_{i} \leqq t \leqq T_{i+1}\right)$ における仕上塗材の拡散係数 $\left(\mathrm{mm}^{2} /\right.$ 年 $)$

$$
D_{c}: \text { コンクリートの拡散係数 }\left(\mathrm{mm}^{2} / \text { 年 }\right)
$$$$
d_{f}: \text { 仕上塗材の塗膜厚さ }(\mathrm{mm})
$$

$x_{i}$ : 時間 $t\left(T_{i} \leqq t \leqq T_{i+1}\right)$ における中性化深さ $(\mathrm{mm})$

$$
A=\left(\sqrt{52 \times \mathrm{CO}_{2} / 5}\right) \cdot A_{5}
$$

ここに、 $A$ : 屋外暴露における中性化速度係数 $(\mathrm{mm} / \sqrt{ }$ 年 $)$

\section{$A_{5}$ : 促進中性化試験における中性化速度係数 $(\mathrm{mm} \sqrt{ }$ 週 $)$} $\mathrm{CO}_{2}$ : 屋外の炭酸ガス濃度 $(0.03 \%)$

透気係数により予測した築年数 37 年の中性化深さと、ドリル法 により測定した中性化深さとの差は $3.3 \mathrm{~mm}$ であり、ほぼ一致して いた。従って、本建物で調査した仕上塗材については、透気係数の 測定結果を用いて推定した中性化抵抗の経年変化より、中性化進行 を予測できることが分かった。

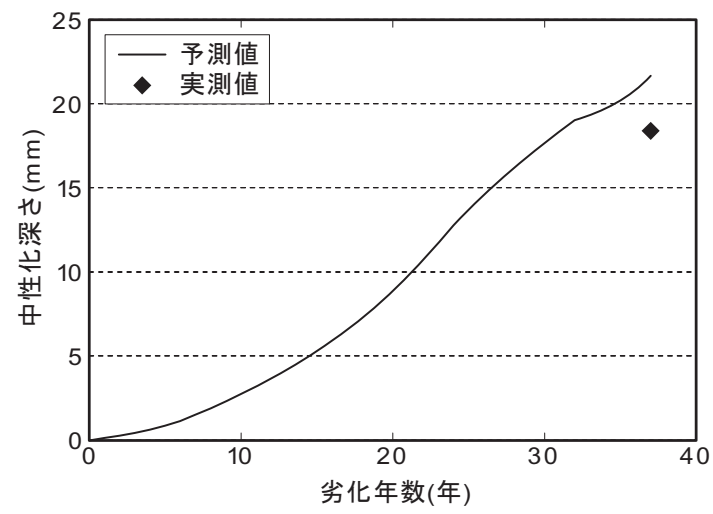

図 8 仕上塗材の経年劣化を考慮した中性化進行予測

\section{5.まとめ}

本研究結果をまとめると、以下の通りである。

（1）促進中性化試験結果、および中性化抵抗の経年変化の予測值よ り改修後の仕上塗材の樹脂塗膜厚さを算出した結果、改修後の 仕上塗材の塗布量は標準塗布量よりも少なかったと推察された。

（2）促進中性化試験結果、透気係数の測定結果、および中性化抵抗 の経年変化の予測值により算出したコンクリートの拡散係数は、 既往の実験值とほぼ一致しており、透気係数による仕上塗材の 中性化抑制効果の評価方法、および中性化抵抗の経年変化の予 測は、妥当であったと考えられる。また、仕上塗材の経年劣化 を考慮した中性化進行を予測する場合、中性化抵抗の経年変化 は図 7 の回帰式で表せる。

（3）透気係数の測定結果を用いて推定した中性化抵抗の経年变化よ り予測した中性化深さは、実測の中性化深さとほぼ一致してお り、透気係数の測定から中性化抵抗を推定でき、中性化進行を 予測できることが分かった。

\section{参考文献}

1）建設大臣官房技術調查室監修，(財)国土開発技術センター建築物耐久性向 上普及委員会：鉄筋コンクリート造建築物の耐久性向上技術，技報堂出 版, 1986

2) R.J.Torrent : A two-chamber vacuum cell for measuring the coefficient of permeability to air of the concrete cover on site, Materials and Structures, Vol.25, No.150, pp.358-365, 1992

3）唐沢智之ほか：仕上塗材の中性化抑制効果と透気性に関する考察，コン クリート工学年次論文集 Vol.30，No.1，pp.645-650，2008

4）唐沢智之ほか：ダブルチャンバー法による仕上塗材の透気係数と中性化 進行予測に関寸る研究, セメント・コンクリート論文集, 第 63 号, pp.435-442，2009

5）唐沢智之，桝田佳宽：既存建物の仕上塗材の透気係数と中性化深さの調 査に基づく仕上塗材の中性化抑制効果，日本建築学会構造系論文集，第 661 号, pp.449-454, 2011.3

6）日本非破壊検查協会：ドリル削孔粉を用いたコンクリート構造物の中性 化深さ試験方法，NDIS 3419-1999

7）河野政典ほか：仕上塗材の経年劣化を考慮した拡散理論に基づく中性化 進行予測に関する研究，セメント・コンクリート論文集，第 62 号, pp.318-325, 2008

8）河野政典ほか：仕上塗材の経年劣化を考慮した中性化抑制効果に関する 研究，日本建築学会構造系論文集，第 584 号，pp.15-21，2004.10

9） 日本建築学会 : 鉄筋コンクリート造建築物の耐久設計施工指針(案) ・同解 説, pp.92-108, 2004

10）日本建築学会：建築工事標準仕様書・同解説，鉄筋コンクリート工事, pp.127-146, 1969

11）国土交通省：公共建築工事標準仕様書建築工事編，pp.152-154，平成 17 年版

12）建設省：建築工事共通仕様書建築工事編, pp.196-197, 昭和 60 年版

13）河野政典ほか：仕上塗材の経年劣化を考慮した中性化抑制効果評価手法 の暴露データによる検証, 日本建築学会構造系論文集, 第 609 号, pp.9-14, 2006.11

14）李榮蘭ほか : 仕上塗材の劣化がコンクリートの中性化進行に及ぼす影響 に関する解析的検討, セメント・コンクリート論文集, 第 63 号, pp.443-44 9,2009 